\title{
Geochemistry of the poritash intrusive complex (Kola Peninsula)
}

\begin{abstract}
Considered geochemistry and geological features of the large subvolcanic intrusions of andesite-dacite composition, were introduced into the tuff-sedimentary rocks of the Southern Pechenga Complex of the Pechenga structure (1940-1700 Ma). Intrusions form of a group of hook-shaped lenticular sub-concordant bodies, reaching a maximum thickness of $1.5 \mathrm{~km}$ at the Poritash fault. They have a cutting contact with the basaltic rocks of Northern Pechenga Complex. In geological literature they are usually called the Early Proterozoic Intrusive Poritash Complex (IPC). An asymmetric structure of a large intrusion of IPC in the Poritash mountain is established. Its roof part is composed of leucocratic dacites, and the plantar part, with a thickness of about $0.5 \mathrm{~km}$ is represented by andesite-dacites and dacites. A whole series of lenticular and subisometric bodies of eruptive breccias of rhyolite composition is confined to the plantar part. The isotope U-Pb age of IPC rocks is 1904 \pm 7 Ma. The Southern Pechenga Complex opens a new stage of formation of the Pechenga-Varzuga Greenstone Belt, where rifting of the Northern Pechenga Complex was replaced by orogenic conditions for the formation of a later Southern Pechenga Complex.
\end{abstract}

Keywords: pechenga structure, early proterozoic, southern pechenga complex, poritash complex, subvolcanic intrusion, poritash fault
Volume 3 Issue I - 2019

\author{
Petr Skuf'in \\ Geological Institute of the Kola Science Center of the RAS, \\ Russia
}

Correspondence: Petr Skuf'in, Geological Institute of the Kola
Science Center of the RAS, Apatity, Russia, Email skuf@geoksc.apatity.ru

Received: October 17, 2018 | Published: January 09, 2019

\section{Introduction}

Considered geochemistry and geological features of the large subvolcanic intrusions of andesite-dacite composition, were introduced into the rocks of the Southern Pechenga Complex of the Pechenga structure (1940-1700 Ma). The Southern Pechenga Complex opens a new stage of formation of the Pechenga-Varzuga Greenstone Belt, where rifting of the Northern Pechenga Complex was replaced by orogenic conditions for the formation of a later Southern Pechenga Complex. A key role is played by medium-acid intrusions of Poritash Intrusive Complex (IPC), being the first signal of the beginning of a powerful volcanic events of the orogenic Vepsian Cycle, when in the Southern Pechenga Zone appeared metallogeny, typical for orogenic periods in the development of ancient Greenstone Belts - formation of carbonaceous metasomatites with elevated concentrations of $\mathrm{Au}$, $\mathrm{Ag}, \mathrm{Sn}, \mathrm{Bi}, \mathrm{Sb}, \mathrm{Pb}, \mathrm{Zn}, \mathrm{W}, \mathrm{As}$. This transition dramatically changes metallogenic backgrounds of geological prospecting in the vast expanse of the Southern Pechenga structure. In this case Sm-Nd data of the medium-acid IPC rocks have characteristics of crustal contamination and are characterized by negative values of $\varepsilon \mathrm{Nd}$ from -3.32 to -4.55 , which is typical for the volcanites of orogenic origin.

\section{Results}

\section{The General condition of the problem}

The Early Proterozoic volcano-sedimentary successions within the Pechenga Structure of the Kola Peninsula belongs to an earlier Northern Pechenga Complex (2550-1940 Ma and a later Southern Pechenga Complex (1940-1700 Ma). ${ }^{1}$ The Pechenga volcano-tectonic structure is the northwestern fragment of the large greenstone PechengaVarzuga Belt, which cuts the whole of the Kola geoblock diagonally from the northwest to the southeast, with a formation period of 25001700 million years. The section of the Southern Pechenga Complex is represented from the bottom up by the volcano-sedimentary rocks of Kallojavr, Bragino, Menel, Kaplja and Kassesjoki suites (Figure 1). A number of the large subvolcanic bodies of andesite-dacite composition were introduced into the tuff-sedimentary rocks of the Kallojavr suite. In geological literature they are usually called the Intrusive Poritash Complex (IPC). To the contact zone of Kallojavr and Bragino suites dedicated Anssemjoki basaltic unit, which is composed of the series of separate overlying chains of bodies and lenses with a power of up to $200-250 \mathrm{~m}$, the section of which is formed by sheets of massive and pillow-lavas, having basaltic, picrobasaltic and ferrobasaltic composition, and layers of gabbro-dolerites, hyaloclastites and tuffites. In the North-West the rocks of this unit can be traced to Lake Poro-jarvi. To the South-East this unit pinch out completely to the East of the River Pechenga.

The area of direct contact of the rocks of Kallojavr suite and a younger rocks of Bragino suite is a sharp transition from monotonic tuffitic section of Kallojavr suite to the zone of the layered tuffsandstones of Bragino suite with lenses and layers of basalts Anssemjoki unit. Himself tectonic contact the rocks of Kallojavr and Bragino suites is a zone of intense cataclasis and mylonitization, area powerful metasomatic processes, with large-scale deposition of carbonaceous matter. In the result the rocks of Kallojavr suite, initially represented by andesitic tuffs and tuffites, in places converted to metasomatic quartz-carbonaceous shale. Characteristically, the formation of carbon tectonite in this area continued throughout the Svecofennian Cycle. This is recorded by the metasomatic formation of carbonaceous shales in the andesites of IPC, introduced in the rock-section of Kallojavr suite in Late Svecofennian Cycle. For the geological section of Bragino suite are also typical the outpouring of andesitic lavas. All these manifestations of basaltic and andesitic volcanic activity were continuously evident in the Svecofennian Cycle, throughout the period of the formation of rocks of Bragino suite and Poritash Complex, being the first signal to the beginning of a powerful volcanic events in the Vepsian Cycle, when in the Southern Pechenga Zone were formed volcanites of the bimodal composition - picrites and picrobasalts of Menel suite and acidic volcanites of Kaplja suite. 


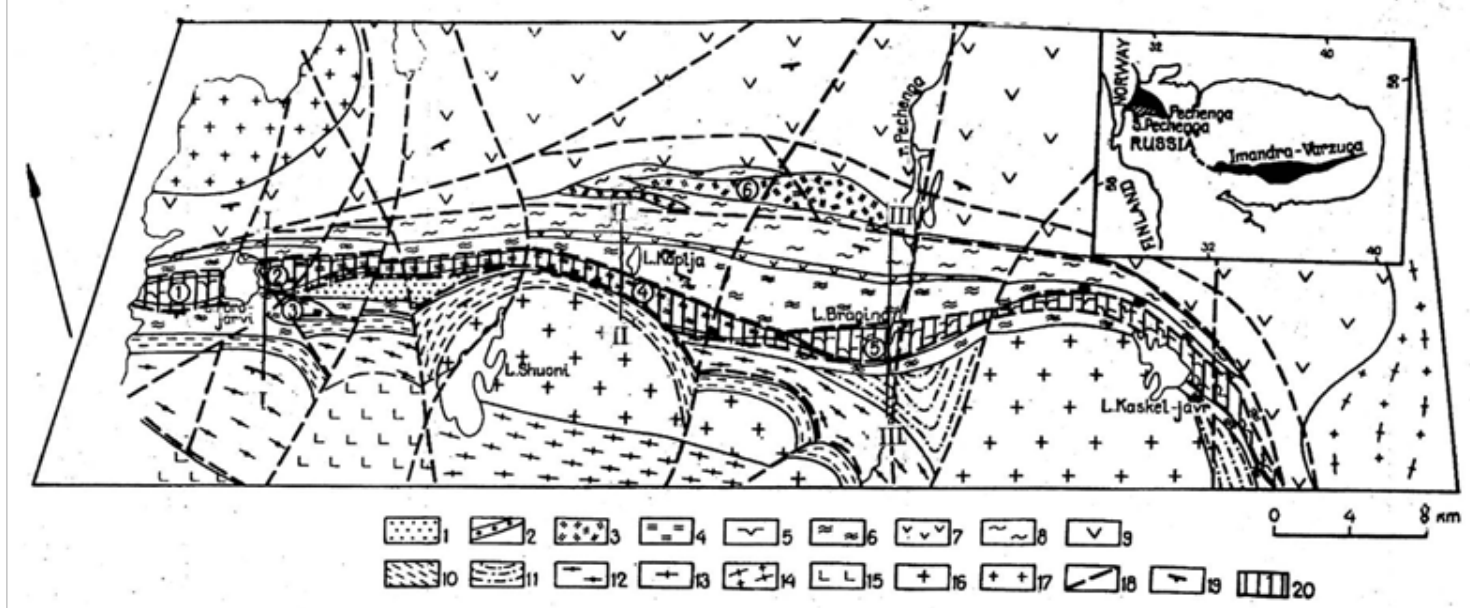

Figure I Schematic geological map of the contact of Northern and Southern Pechenga complexes; 1-7, rocks of the Southern Pechenga complex (1940$1700 \mathrm{Ma}$ ): I,2,4,5, rocks of the Vepsian Cycle: I-2, Kassesjoki suite: I, tuff-conglomerates; 2, tuffs; 4, medium-acid volcanites of Kaplja suite; 5, basite volcanites of Menel suite; 3, rocks of subvolcanic intrusions of IPC (I904 \pm 7 Ma) for the Late Svecofennian Cycle; 6-7, rocks of Bragino suite of the Early Svecofennian Cycle: 6, tuff- sedimentary rocks; 7, Anssemjoki basaltic unit; 8,9, Northern Pechenga complex: 8, tuffs of Kallojavr suite of Kalevian Cycle; 9, volcanites of Matert suite of Kalevian Cycle; 10, Complex of schistose amphibolites in the Southern boundary of Pechenga structure; II, rocks of unclear stratigraphic position; 12, gneiss-schists of the Talja suite (Lower Proterozoic?); I3, Archaean gneiss-granites; 14, granites of the Ara-Guba intrusive complex (I840 Ma); I5, gabbro of Kaskama-Shuort intrusive complex (Lower Proterozoic?); 16, granites of the Southern boundary of Pechenga structure (1940 Ma); 17, granites of the Northern boundary of Pechenga structure (2720 Ma); 18, faults; 19, occurrence of rocks; 20, Porojarvi orogenic belt, which controlled the localization of autonomous volcanic centers (volcano-tectonic structures) of Vepsian Cycle: I, Pasvik; 2, Northern Porojarvi; 3, Southern Porojarvi; 4, Kaplja; 5, Bragino; 6, Poritash rocks of Late Svecofennia Cycle.

\section{Geology and geochemistry of the intrusive complex poritash}

The subvolcanic intrusions of IPC rocks are stretched in the form of a group of large hook-shaped lenticular sub-concordant bodies reaching a maximum thickness of $1.5 \mathrm{~km}$ at the Poritash fault intersection site with a transverse deep Hihnajarvi fault. Intrusions have cutting contact with basalts of the Matert suite and tuffs of the Kallojarv suite. The slashing nature of the contacts is proved by the presence of xenoliths of basalts and tuffs in endocontact intrusions. An asymmetric structure of a large intrusion of IPC in the Poritash and Lac-Poritash mountains is established (Figure 2). Its roof part is composed of leucocratic dacites, and the plantar part, with a thickness of about $0.5 \mathrm{~km}$, which stands out well on magnetic and gravimetric maps, is represented by andesite-dacites and dacites. A whole series of lenticular and subisometric bodies of eruptive breccias of rhyolite composition is confined to the plantar part.

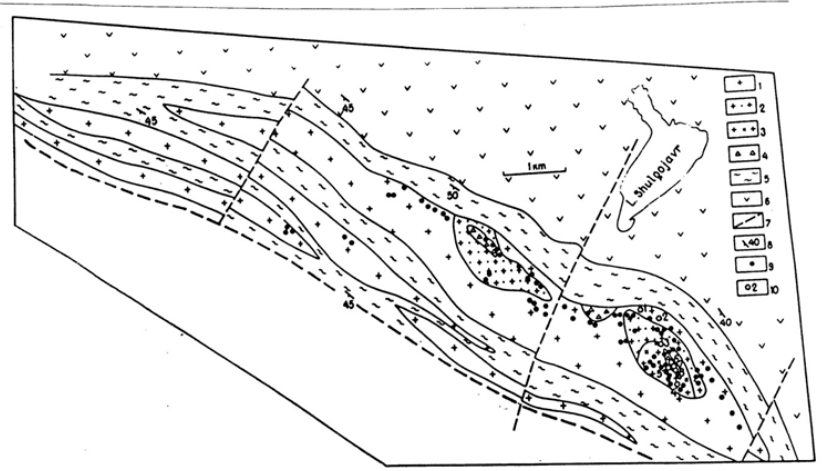

Figure 2 Schematic geological map of the IPC.' I-4, volcanites of IPC: I, dacites and andesite-dacites (less than $5 \%$ of mafic phenocrysts); 2 , andesites and andesidacites (5-15\% of mafic phenocrysts); 3 , andesites (more than $15 \%$ of mafic fenocrists); 4 , rhyolites of eruptive breccias.
Table 1 shows the average composition of medium acidic and acidic rocks of IPC and coeval and esites of the Kaplja suite. In Table 2 shows the isotopic $\mathrm{Sm}-\mathrm{Nd}$ data for the rocks of IPC and for the rocks are close in age formations of the Pechenga structure. Volcanites of IPC have characteristics of crustal contamination and are characterized by negative values of $\varepsilon \mathrm{Nd}$ from -3.32 to -4.55 . The isotope $\mathrm{U}-\mathrm{Pb}$ age for the three types of zircons is $1904 \pm 7 \mathrm{Ma}$, the coordinates of the two points have a near-concordant position, the new age of volcanites obtained is interpreted by the formation time (Figure 3 ).

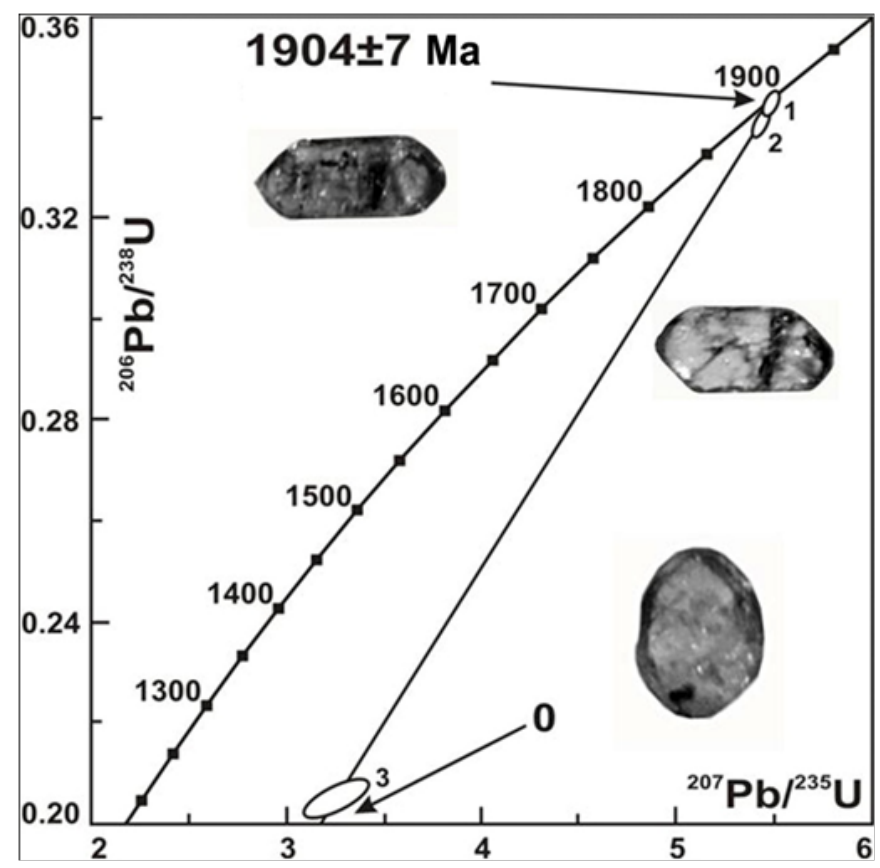

Figure 3 Isotopic U-Pb diagram with a concordium for zircons from rocks of IPC. 
Table I Average compositions of volcanites of the IPC and Kaplja suite

\begin{tabular}{llllllll}
\hline Components & $\mathbf{I}$ & $\mathbf{2}$ & $\mathbf{3}$ & $\mathbf{4}$ & $\mathbf{5}$ & $\mathbf{6}$ & $\mathbf{7}$ \\
\hline $\mathrm{SiO}_{2}$ & $\mathbf{n = 3 0}$ & $\mathbf{n}=\mathbf{7}$ & $\mathbf{n}=\mathbf{5}$ & $\mathbf{n}=\mathbf{I}$ & $\mathbf{n = 1 9}$ & $\mathbf{n}=\mathbf{5}$ & $\mathbf{n = 6}$ \\
$\mathrm{TiO}_{2}$ & $63.1 \mathrm{I}$ & 66.7 & 72.86 & 60.42 & 58.57 & 66.14 & 73.82 \\
$\mathrm{Al}_{2} \mathrm{O}_{3}$ & 0.92 & 0.83 & 0.42 & $0.8 \mathrm{I}$ & 0.76 & 0.6 & 0.54 \\
$\mathrm{Fe}_{2} \mathrm{O}_{3}$ & 13.92 & 12.57 & $11.4 \mathrm{I}$ & 16.16 & 14.53 & 12.59 & 12.27 \\
$\mathrm{FeO}$ & 2.4 & 2.26 & 0.67 & 1.1 & 1.65 & 0.72 & 0.23 \\
$\mathrm{MnO}$ & 4.47 & 3.94 & 2.67 & 5.04 & 4.19 & 4.21 & 2.15 \\
$\mathrm{MgO}$ & 0.08 & 0.07 & 0.04 & 0.09 & 0.09 & 0.07 & 0.05 \\
$\mathrm{CaO}$ & 2.49 & 2.15 & 0.65 & 2.86 & 3.81 & 1.69 & 1.16 \\
$\mathrm{Na}_{2} \mathrm{O}$ & 3.47 & 1.97 & 2.73 & 2.31 & 4.89 & 3.69 & 1.45 \\
$\mathrm{~K}_{2} \mathrm{O}$ & 2.7 & 3.58 & 1.17 & 4.68 & 3.82 & 4.5 & 3.77 \\
$\mathrm{P}_{2} \mathrm{O}_{5}$ & 2.9 & 2.44 & 5.78 & 3.18 & 3.24 & 2.09 & 1.97 \\
$\mathrm{CO}_{2}$ & 0.2 & 0.2 & 0.12 & 0 & 0.26 & 0.2 & 0.17 \\
$\mathrm{~S}$ & 0.06 & 0.14 & 0.06 & 0 & $1.5 \mathrm{I}$ & 0.1 & 0.41 \\
$\Sigma$ & 0.08 & 0.06 & 0.29 & 0 & 0.03 & 0.01 & 0.03 \\
\hline
\end{tabular}

I-7, Southern Pechenga complex; I, andesite of IPC; 2, dacite of IPC; 3, rhyolite of IPC; 4, tuff of Kallojavr suite; 5, andesite of Kaplja suite; 6, dacite of Kaplja suite; 7, rhyolite of Kaplja suite.

Table 2 Sm-Nd data for the rocks of the IPC and and Kaplja suite

\begin{tabular}{|c|c|c|c|c|c|c|c|c|c|}
\hline \multirow{2}{*}{ Sample } & \multirow{2}{*}{ Rocks } & \multirow{2}{*}{ Suite } & \multicolumn{2}{|c|}{ Content, ppm } & \multicolumn{2}{|l|}{ Isotopic ratios } & \multirow{2}{*}{ TDM } & \multirow{2}{*}{ Age } & \multirow{2}{*}{$\varepsilon \mathbf{N d}(T)$} \\
\hline & & & Sm & Nd & $\mathrm{Sm} / \mathrm{I} 4 \mathrm{Nd} / 47$ & |43Nd//44Nd & & & \\
\hline $88-8$ & Andesite & \multirow{4}{*}{ Kaplja suite } & 9.17 & 52 & 0.1066 & $0.511243 \pm 9$ & 2703 & 1904 & -5.21 \\
\hline $88-26$ & Andesite & & 8.11 & 46.3 & 0.1058 & $0.511217 \pm 4$ & 2719 & 1904 & -5.53 \\
\hline $88-30$ & Andesite & & 8.38 & 47.3 & 0.1072 & $0.511264 \pm 5$ & 2688 & 1904 & -4.95 \\
\hline SU-2 & Andesite-basalt & & 7.13 & 39.2 & 0.1101 & $0.511393 \pm 5$ & 2575 & 1904 & -3.13 \\
\hline S- $14 \mid$ & Dacite & \multirow{2}{*}{ Rocks of IPC } & 2.22 & 10.14 & 0.1323 & $0.511542 \pm 7$ & 2995 & 1904 & -5.66 \\
\hline S-142 & Rhyolite & & 4.94 & 24.3 & 0.1231 & 0.5|| $48 \mid \pm 8$ & 2795 & 1904 & -4.59 \\
\hline
\end{tabular}

The age of the rocks is comparable to the age of the plagiogranites of the Shuonijavr massif and the quartz diorite of the Kaskeljavr massif in the Southern frame of the Pechenga structure, respectively $1939 \pm 7 \mathrm{Ma}$ and $1940 \pm 17 \mathrm{Ma},{ }^{3}$ and $1907 \pm 18 \mathrm{Ma}$ with the trachydacites of the Panarechka structure. ${ }^{2}$

\section{Discussion}

In the published paper, the features of the structure and composition of the subvolcanic Intrusive bodies of Intrusive Poritash Complex (IPC), formed during the eruption of the Autonomous Poritash Volcanic Center. This center representatives the whole group of volcanic structures in the framework of Svecofenno-Vepsian orogenic volcanic Belt (SVB), a legacy developed on the southern flank of the large greenstone Pechenga-Varzuga Belt (PVB) in the Late Svecofennian Cycle (Figure 1). Svecofenno-Vepsian Belt is unique to the Early Precambrian the result of geological evolution of the largest riftogenic structure of Kola region - PVB, at a late stage of development which was formed the SVB. This geological event was the reflected form of large-scale geodynamic processes in the Svecofennian geosynclinal in Finland. The reduced permeability of the earth's crust caused the change of rift-related basalt formations of tholeitic series of Northern Pechenga complex in the andesite and andesite-dacite formations of calc-alkali series in the Southern Pechenga complex. These formations are indicators of environments of orogenic compression, which was typical for the main stages of development of geodynamics of the Svecofenno-Vepsian Cycle.

Felsic volcanites, identifying the orogenic stage of development of the SVB, formed typical for such environments volcanic structures, in much the same to linear and isometric volcanic structures of orogenic volcanic belts in the Phanerozoic. Among them caldera-like multi-tiers volcano-tectonic structures, eruptive volcanic centers and volcanic domes. It should be borne in mind that a good knowledge of the geology of the Pechenga structure refers primarily to the Northern part of the structure, which was mainly conducted largescale exploration activities, where all open and development of the field of $\mathrm{Cu}-\mathrm{Ni}$ ores, as well as the entire industrial infrastructure, road 
network, cities and towns. At the same time poorly studied Southern Pechenga Zone have been studied sporadically, and the number of publications devoted to this region, is extremely small.

In the Southern Pechenga Zone, the author was directly involved in all major research and production projects of its study, in particular, provided scientific guidance during 1987-95 in the works for scientific, production program GDP-50 (geological survey of scale 1:50,000) within the Southern Pechenga Zone. In the framework of the Russian-Norwegian programme "Northern project" the author in 1989-93 participated in the project "Pechenga-Pasvik-Polmak greenstone Belt". The result of these studies was the development of the first Norwegian-Russian geological map of the Pechenga-Polmak belt of scale 1:100000, as well as Lithological and geological map of scale 1:25000 of the border area. Thus, a significant part of the unpublished materials relating to the Geology of the SvecofennoVepsian volcanic formations of Southern Pechenga Zone used in this publication. As a result of the studies, which allow us to consider the entire Southern Pechenga Zone as a typical orogenic volcanic belt with a set of volcano-tectonic structures and volcanic centers, are changing geodynamic and metallogenic understanding of the prospects of further exploration of this territory.

\section{Acknowledgment}

Research conducted with the support of grant No. 16-05-00026.

\section{Conflicts of interest}

The author declares that there is no conflicts of interest.

\section{References}

1. Skuf'in PK. Early Proterozoic volcanogenic formations PechengaVarzuga belt. Author's abstract of the doctoral dissertation. Ed. Moscow state University (MSU). Moscow: 1998. p. 66.

2. Skuf' in PK, Bayanova TB, Mitrofanov FP. The isotope age of subvolcanic granitoid rocks of the Early Proterozoic Panarechka volcanic-tectonic structure (Kola Peninsula). DAN. 2006;409(1):774-778.

3. Skuf'in PK, Bayanova TB, Mitrofanov FP, et al. The absolute age of the Shuoni-javr intrusive granites from the southern frame of the Pechenga structure (Kola Peninsula). DAN. 2000;370(2):227-230. 